\title{
オーストリア・ウィーン市におけるグリーンベルト 政策の变遷と近年の動向に関する考察
}

\author{
The History and Latest Policies on the Vienna Green Belt
}

\author{
寺田徹* 横張 真 ${ }^{* *}$ 雨宮 護 ${ }^{* *}$ \\ Toru TERADA Makoto YOKOHARI Mamoru AMEMIYA
}

\begin{abstract}
The purpose of this study is to investigate the history and recent policies on the Vienna green belt and to discuss its future direction. In 1905 the "Viennese wood and meadow belt" was formally established as a conserved open space area by the Vienna city council. Since then the green belt has been enlarged by strengthening restrictions in other areas. Today it comprises about half the area of Vienna. In the latest urban development plan ("STEP05") the conservation and further expansion of the green belt was expressed as a key objective. In our study we introduce some of the key policies for achieving this objective. For example, the Agricultural-Structural Development Plan ("AgSTEP") to conserve suburban agricultural land and the Biosphere Park Wienerwald, an initiative by UNESCO to ensure the conservation of the green belt by strengthening its biodiversity. In conclusion, the Vienna green belt can now be regarded as a regional scale open space planning scheme to secure the existing characteristics of Vienna and its surrounding regions. For the strengthening of this direction, a "layering approach" which applies several policies together is established.
\end{abstract}

Keywords: Vienna, Wien, green belt, history, wide-range cooperation キーワード：ウィーン，グリーンベルト，歴史的経緯，広域連携

\section{1.はじめに}

都市の無秩序な拡大を抑制することは，近代都市計画における 至上命題のひとつであり，その有力な手段としてグリーンベルト （以下，GB）が位置づけられてきた。しかし近年では，その賛否 をめぐって多方面から議論がなされている。GBは，これまでの 役割を見直すべき転換期に差し掛かっているといえる。

GB に対する否定的見解は，その強すぎる計画規制が自由な経 済活動や居住地選択の妨げになっていることや，GB を飛び越え た無秩序な開発を誘発するというものである ${ }^{1)},{ }^{2)}$ 。一方, GB に 対する肯定的見解は, 都市気候の緩和や, 都市への新鮮な農作物 の提供，また都市住民のレクリエーション利用などの役割を通し て, 都市の持続可能性を保証する手段として GB を積極的に認め ようとするものである ${ }^{3)}$ 。 GB をめぐる政策的対応は, 世界的な 潮流としては前者が優勢であり, ロンドン, ソウルをはじめ各国 の GB の多くは，実際に指定解除の傾向にある $\left.{ }^{1)}, 2\right) 。$

こうしたなか，オーストリア・ウィーン市は，2005 年に 「都市発展総合計画 (Stadtentwicklungsplan Wien2005 “STEP 05” ${ }^{4)} 」($ 以下，STEP05）を策定し，世界的な潮流に反して，GB の計画規制を強化する方向を示した。本事例は, 指定解除が世界 的な趨勢となっている GB について, 新たな議論を喚起するもの となるばかりでなく, わが国の今後の都市および郊外での緑地保 全のあり方に対しても，多くの示唆をもたらすことになろう。

本稿では, STEP05, および関連政策の報告を通じ, 将来の GB 政策のあり方について考察を行う。具体的には，まず，GB 政策の歴史的経緯について整理する (第 2 章)。次に, そうした 流れの延長線上に位置付けられる STEP05 の概要を, 事例紹介 を交えつつ報告する (第 3 章)。最後に, 以上の内容を踏まえ, 今後の GB 政策のあり方について考察する (第 4 章)。

なお， ウィーン市の都市計画・緑地計画については, 三島らの 一連の研究 $\left.{ }^{5,}, 9\right)$ や, 加藤 ${ }^{10)}$ に詳しい。しかし, 本稿はそれらと 異なり, 広域緑地計画的視点から GB を評価している点, 十分な
報告例がない STEP05 を中心に議論を展開する点に特徵がある。

\section{GB の歴史的経緯と現況}

GB の歴史的経緯を整理するにあたっては，主に“100 jahre Wiener Wald- und Wiesengürtel, 1905-2005”11) を用いた。同 資料は, GB 政策 100 周年を記念してウィーン市により発行され たものであり，有限会社 PlanSinn ${ }^{12)}$ の編集のもと，GB の政策 の歴史や将来の方向性等に関して, 行政や教育研究に携わる様々 な著者によって，詳細に述べられている。

\section{（1）緑地帯思想の発達（1860～1900 年代）}

1866 年のプロシア戦争に敗れて財政難に陥ったオーストリア 政府は，1870 年に国家財産売却のための法律を定めた。同法に 基づき, 政府が材木商モーリッツ（Moritz Hirschl）とウィー ンの森の伐採許可に関する契約を結んだことにより， ウィーンの 森は危機に瀕することになる ${ }^{13)}$ 。対して，一民間人であったヨー ゼフ・シェッフェル (Josef Schöffel) により，市民による反対 運動が展開された（1870～72 年)。結果, 政府は 1872 年に法律 を撤回することになり，モーリッツとの契約も取り消しとなった。

このように市民の緑地保全意識が高まる中，市当局は 1893 年 のウィーン全体調整計画（Generalregulierungsplan）策定のた めの設計競技を開催した。設計競技に優勝したのは，建築家オイ ゲン・ファスベンダー (Eugen Fassbender) である。その提案 は，「国民リング (Volksring)」と称され，「市の中心部を中心 とした, 半径 $5 \mathrm{~km}$, 幅 $600 \mathrm{~m}$ の緑地帯を設置する ${ }^{13)} 」$ というもの であった。このファスベンダー案を元にして緑地帯構想の実現性 が検討され，GB が策定された ${ }^{8)} 。$

（2）森・草原ベルトの策定から戦中・戦間期（1905～1945 年）

ウィーン市の GB は 1905 年の「森・草原ベルト保全地域 (Schutzgebiete Wald- und Wiesengürtel ; 以下 Sww) $\left.{ }^{14}\right\rfloor$ の指 定て始めて制度化され，4,400ha ${ }^{15)}$ の緑地に開発規制がかけられた。

当時のウィーン市では，過去最大である 200 万人以上が，現在

\footnotetext{
*筑波大学大学院システム情報工学研究科 ${ }^{* *}$ 東京大学大学院新領域創成科学研究科 ${ }^{* * *}$ 科学警察研究所犯罪行動科学部
} 
とほぼ同面積の範囲に居住しており，大変な過密状態にあった。 それ故, GBに対しては都市環境を健全に保つことが強く求めら れており,「北西部の緑地を保存し, 都市へ流れ込む新鮮な空気 を供給する ${ }^{16)} 」$ 役割が期待されていた。

こうした環境保全上の機能と同時に, 薪炭等燃料の供給源とし ても用いられていた GB であるが, 特に第一次世界大戦直後の数 年間は, 燃料難を背景とした冬期の過剩な薪炭取得によって荒廃 することとなる ${ }^{17)}$ 。また, 戦間期においては, 住宅難や貧困, 王 政崩壊による移民増によって, GBの一部は指定解除され, 住宅 用地や市民農園（Kleingärten）に転換させられた ${ }^{9), 17) 。 ~}$

すなわち, 当初は環境保全上の目的から設置された GBであっ たが, 社会的に不安定な戦中・戦間期においては火急的課題の解 決が優先され，量的にも質的にも荒廃することとなったのである。 実際に, 1930 年に 5,200ha まで増加した Sww の指定面積は, 1945 年においては 4,874 ha まで減少している ${ }^{8)}$

（3）スプロールの進行と GB の制度的補強（1945～1990 年）

戦後の GB は, 戦中から続いた荒廃に対処すべく, 新たな法制 度上の位置づけを獲得する。

二度の大戦により, ウィーン市では全住宅の $20 \%$ 以上，およ そ87,000 戸が半壊または全壊した ${ }^{18}$ 。住宅難を解決するために 近代住宅の建設が進み, GB を侵食する形で, 特に都市周縁部に おけるスプロール開発が顕著となった ${ }^{19}$ 。

こうしたなか，1955 年にウィーン州自然保全法（Wiener Naturschutzgesetz）が改正され，GBの保全地域が自然保全法 における「風景保全地域 (Ladschaftsschutzgebiet)」を根拠と するようになった ${ }^{8)}$ 。れにより，今まで保全が困難であった地域を 風景保全の観点から GB に導入できるようになり，実際に 1965 年にビザムベルク（Bisamberg）の一部が Sww に指定された。

1970 年代には, 良好な環境を求める住民の立場から, 緑地の 多い郊外部への人口の集中はより顕著となる一方, ドナウ川の中 州においては人工島が建設され，レクリエーション機能を有する 緑地も補完された（1978 年に一部が Sww 指定）。

（4）移民による人口増に対応した GB の指定強化（1990 年〜） 1990 年の初頭以降, 冷戦の終結による移民増を背景として, 再び人口が増加した。人口の受け具としての郊外への居住の要請 が高まるなか，GB は再び存在意義を問われることとなった。こ れに対してウィーン市は, 再び GB を強化する方向で対応する。

具体的には, 土地収用を基本とした永続的な農地保全手法であ る 1,000ha プログラム (1,000Hectare Programme；1994〜1995 年）や，GB の新たな指定カテゴリである「森・草原ベルト農地 保全地域」(Schutzgebiet Wald- und Wiesengürtel, der landwirtschaftlichen Nutzung vorbehalten; 以下 SwwL) ${ }^{20)}$ の 導入等がみられた。また, 1995 年には GB の包括的なコンセプ トである「ウィーン・GB1995 (1995 Grüngürtel Wien Gesamtplan)」を発表した。そこでは, 様々な緑地をシステマティック に配置，ネットワーク化することによって，GB を完成させよう とする意罒が示されている ${ }^{21)}$ 。

\section{(5) GB の現況}

2005 年現在, GB の面積は 21,500ha（市域の約 50\%）となり, うち約 12,000ha が Sww 及び SwwL に指定され, 開発規制下に ある ${ }^{13)}$ 。市当局が所有している GB も多く, 市内に位置するウィー ンの森（約 5,000ha）のほぼ 4 分の 3 が市当局の所有である。ま た市の北東部に位置するビサムベルク（Bisamberg）の丘のう ちの 255 ha 等も市当局の所有地である ${ }^{22}$ 。一方, 市域の北東部や 南部に卓越する，GB に指定された農地の大半は，民有地である。

\section{3 ． 近年の GB 政策}

\section{(1) GB 政策見直しの背景}

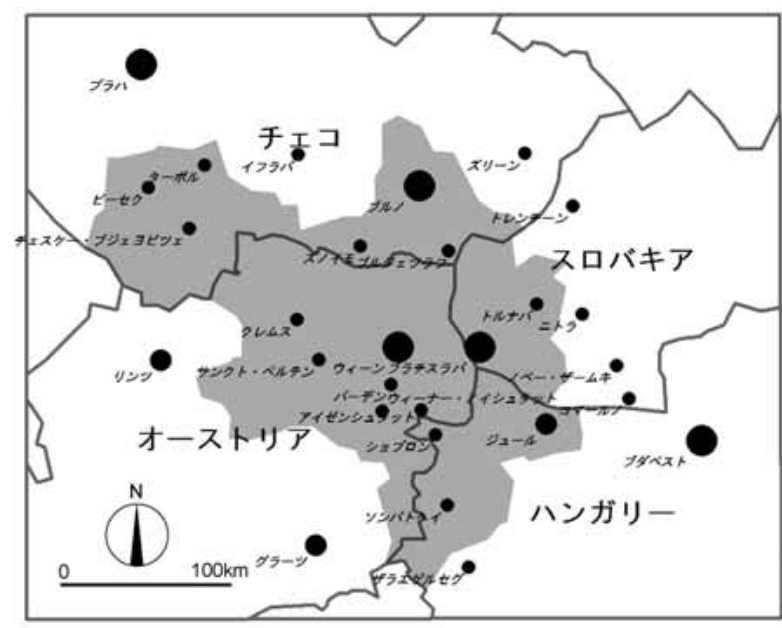

図一 1 CENTROPE の範囲

(Central European Region (2007) ${ }^{23}$ を基に作成)

近年のウィーンの GB 政策に大きな影響を与えたのは，中欧諸 国の加入による $\mathrm{EU}$ 圈の拡大である。このことに対応して, 既存 の行政界を超えた，より広域的な地域（region）における枠組 みが必要となった。ここで, 地理的にも経済的にも中欧の核とな り得るウィーンは, “Think European - act regionally - develope Vienna” ${ }^{18)}$ をコンセプトとして，地域での競争的，かつ共同的 な発展を基本とした開発の方向性を提示することで, 中欧におけ るイニティアティヴを示そうとした。

こうした取り組みは，CENTROPE (Central European Region: : 中欧地域)をひとつの範囲として推進されている（図一 1 )。CENTROPE はチェコ，スロバキア，ハンガリー，オーストリ アの 4 カ国から成る共同体であり, 住宅開発, 交通インフラの整 備，商業や業務施設の配置，貴重な自然の保存などを，地域の総 合的な発展のため, 地域連携の下で行う事を目的としている ${ }^{23)}$ 。

\section{(2) STEP05 の概要 ${ }^{4)}$}

GB 政策の見直しが反映され，その将来の方向性について示さ れたのが, 2005 年に発表された最新の都市発展総合計画である, STEP05 である。STEP (Stadtentwicklungsplan) は，「都市計 画や都市開発の見通しをたて, 将来へ向けて促していくための総 合的な計画」とされ, 内容としては, 我が国の都市計画マスター プランに相当している。

STEP05においては,「生活の質 (Lebensqualität)」,「持続可 能性（Nachhaltigkeit）」，「市民参加（Partizipation）」，「男女 共同参画 (Gender Mainstreaming)」,「多様性 (Diversität)」 を原則として，以下の目標が定められた。

・投資を促すための経済活性化

・地域内における持続可能な資源・エネルギーの供給

・ 生活の質を高めるための GB の拡大

- 自然資源利用の節約

- 公共交通軸への都市開発の集約

- 公共交通依存型の交通計画, 渋滞の緩和

また，上記の目標を達成するために, STEP05 は, 様々な個別 政策を統制する上位計画としての役割も有している。

\section{（3）STEP05 における GB の位置づけ}

STEP05においては，開発限界線を明確に定めることによって, 開発を促す地区と周囲の緑地帯を明確に区分している。開発を促 す地区においては，さらに「都心高密地区（Dicht bebautes Stadtgebiet)」「開発集中軸 (Siedlungsachsen/ -schwerpunkte)」 「郊外低密地区 (Bebaubares Stadtgebiet)」の 3 つのゾーニン グ24) を設定し, 密度管理も目指している。周縁部の緑地帯は, 


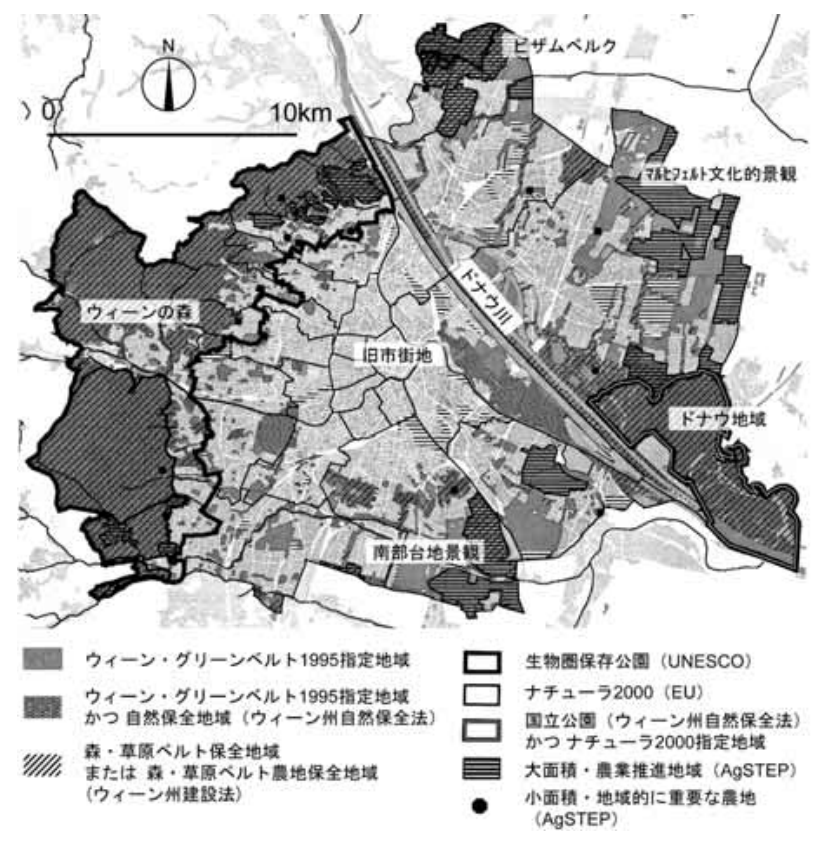

図－2 様々な GB 政策の適用状況 (Stadt Wien (2005) $)^{4)}$ に加筆) （括弧内は根拠法もしくは対応する政策名，組織名）

「ビザムベルクーワインフィアテル南部（Bisamberg - Südliches Weinviertel)」「マルヒフェルト文化的景観（Kulturlandschaft Marchfeld)」「ドナウ地域 - ドナウ湿地国立公園（Donauraum Nationalpark Donauauen) 」「ウィーン南部台地景観 (Terrassenlandschaft im Süden von Wien)」「ウィーンの森 (Wienerwald)」の $5 つ に$ 分類され (図 -2 ), それぞれについ て個々の土地被覆の特徴や, 地政学的特徴を反映させる形で, 取 り組みの方向性が定められている。

これら GB については, 開発規制の強化と地域への拡大が大き な目標とされており，以下のような具体的政策が展開されている。

\section{（4）GB 政策に見られる新たな保全策}

- 都市近郊農地の積極的な保全：AgSTEP（農地開発計画；Agr arstruktureller Entwicklungsplan für Wien 2004) ${ }^{25)}$

ウィーン市においては, 低地帯である市北東部, および南部に おいて農地利用が卓越しているが，同様に人口増も著しい。従っ て, 都市近郊農地において土地利用転換を防ぐことが，GB の保 全にとって緊契の課題として位置付けられている。

AgSTEP は 3 つのゾーニングによる農地保護政策であり, 現 在, 全農地の約 7 割, 約 4,800ha の農地が指定を受けている。指 定された農地は特に市域のフリンジ部分に多く分布している。3 つのゾーンングの概要は，以下のとおりである。

- カテゴリ 1 : 特に優先的に農作物の生産が行われ, 農業利用 が卓越している大面積の農地

- カテゴリ 2 : カテゴリ 1 のうち, 用途転換の可能性があり, 永続的な農地利用が補償できない農地

・ カテゴリ $3:$ 特に地区的な意味において重要な農地

AgSTEPにおいては, とりわけ指定から 10 年間の初期段階に おいて, 農作物の市場保護や助成金制度の利用, 及び都市計画部 門との連携等のもとで，農地保護を推進していくこととなっている。

なお，AgSTEP は既に 2004 年から単独の政策として機能して いたが, STEP05 に位置付けられることにより, その他の GB 政 策との連携が計られることとなった。政策実現の背景としては, 農作物の生産者と消費者の近接によるメリットや, 都市気候の緩 和効果, 都市住民のレクリエーションの場としての利用価值等, 都市近郊農地の優位性が, 都市計画の立場からも, 生活の質の向
上に資するとして評価された事が大きい。

- 生物多様性の保全：ウィーンの森生物圈公園（Biosphären park Wienerwald) ${ }^{26)}$

ウィーンの森生物圈公園は，1971 年に創設されたユネスコの 人間と生物圈計画 (Man and the Biosphere : MAB) が設定す る, 生物圏保存地域（Biosphere reserve）のひとつである。1976 年の設立当初は 56 箇所の指定に留まっていたが, 現在は 97 か国, 440 箇所までに広がっている。生物圈保存地域においては,「統 合された地域において生物多様性の管理が展開され, 実験や普及 啓発が行われる」こととされ, 以下の機能を満たすことが求めら れている。

- 自然保護：生物多様性（生態系，種の多様性，遺伝子の多様 性）を保全する

- 開発：地域の経済を育て, 社会文化的, 経済的な持続可能性 を補償する

・後方支援：国際研究やモニタリングのための資源供給を行い, 環境教育や，環境に関連する情報を一般に提供する

ウィーンの森の一部であるラインッァー・ティアガルテン （Lainzer Tiergarten）は，更に EU 規模の自然保護区のネット ワークである NATURA2000 にも指定されている。ウィーンの 森においては, Sww 指定に重ねる形で, 広域圈における政策之 の連携により，特に生物多様性面での機能を保全することを目的 として GB の強化がなされている。

このように，異なる政策を積層的に投じる手法は，STEP05 が 様々な政策を統合する役割を有しているがために，その他の GB 指定地域においても同様に取り入れられている（図－2）。

・ローカルな規模での物質循環：コンポストを通じた有機性資 源の循環

本事例は STEP05 に位置付けられてはいないが，今後の GB 政策の補強にあたって重要な役割を担うと考えられるため，市の 担当局に対してヒアリングで を行い，概要を把握した。

ウィーン市においては，廃棄物処理・清掃課（MA48）を中心 として, 有機性廃棄物（家庭加発生する厨芥や庭木剪定枝・芝, 公共の緑地から発生する剪定枝や刈り込み草, 農地から発生する 農作物生産時の残渣物等）を一挙に収集し，大規模なコンポスト 化を行っている。収集については MA48 が全体の約 80\%を担当 し，残りの $20 \%$ は間企業が補完している。2006 年度は約 96,000t の有機性廃棄物から, 約 30,000t のコンポストが生産さ れた。

コンポストの約 6 割は市の保有する農地や公園緑地に還元され, 3 割は市民に無償で提供, 残りの 1 割は民間企業へ売却された。 コンポストの品質は第三者機関によって保証され，Aもしくは A+の評価を得ているため, 安全面も保障されている。

事業の成立に関しては, 市民による費用負担に依るところが大 きい。市民は自らが排出した廃棄物の量に基づき，対価を MA48 に支払う。従って, 支払額は個人によってまちまちである ${ }^{28)}$ 。

このように，緑地を介した有機物の循環が既に行政主導の下で 行われており，そのシステムは市民や民間企業との共同作業によっ て成立していた。同システムにおいては，単なる廃棄物削減策に とどまらない, 有機物の循環, 有機栽培による安全な農作物の生 産等, 都市近郊農地が持ちうる多面的な機能を発現させる効果が 期待される。また, 都市内緑地との相互補完的な関係のもとでシ ステムを成立させていることも注目される。このことは, 都市内 緑地を含めた体系的な緑地ネットワークを構築していくという， GB の将来的な方向性を支援するものとして期待されよう。

\section{4.まとめ}

以上，本稿においてはオーストリア・ウィーン市の GB につい 
て, その歴史的経緯と最新の政策の動向について報告した。特に 強調すべき点を, 以下の 3 点にまとめる。

第 1 は, GB に環境保全上の様々な機能を求めていることであ る。例えば, GB のなかの農地については, 都市への新鮮な農作 物の提供, レクリエーション利用, 有機性廃棄物の循環, 樹林地 については，生物多様性の保全が，とくに重視されている。こう した各種の環境保全機能の発現を GB 政策の基本的な柱のひとつ に据えていることは, 持続可能性という世界中の都市が今日直面 している課題に対し, 抽象的な概念や理想論ではない, 現実的な 解を与えたものとして，きわめて重要であると考えられる。

第 2 は, 様々な環境保全上の機能の発現を図る上で, 各種政策 を重層的に講じていることである。なかでも，こうした重層的な 政策展開を担保するために, 既存の行政上の枠組みを超え, 他自 治体との広域的な連携を積極的に図ったり, 他部門との横断的な 連携を図っていることが，大きな特徵だと考えられる。

第 3 は, こうした様々な政策を統括する存在として, 上位計画 である STEP05 を位置づけていることである。重層的な政策展 開は, ともすると制度上の煩雑さを招いたり ${ }^{2)}$, 開発に際して逃 げ道を生み出す ${ }^{29)}$ という批判もある。しかしながら，上位計画 である STEP05 の統制のもとで個別政策を機能させることによ り，そうした危険性を回避しょうとしているものと考えられる。

\section{5. ウィーン市の事例が今後の都市緑地政策にもたらすもの}

GB の維持に関しては，冒頭にも述べたように，本来的な意義 である無秩序な市街化の抑制に対して, その効果を疑問視する意 見が多い。こうした見解のもとGB の指定解除が相次いでいる現 在, 屯はや市街化抑制を第一義として GB を維持していく事は困 難であろう。しかし，では GB に象徴される広域緑地が，今後の わが国と世界の都市にとって不要なのかと言えば，情勢はむしろ 正反対である。温暖化や資源の枯渇に対して, $\mathrm{CO}_{2}$ 削減や微気象 緩和，フードマイレージの削減等によって環境負荷を極力低減し， 持続的な発展が可能な都市圈を形成することは, 世界各国が共通 して取り組むべき焦眉の課題であり, GB に代表される広域緑地 の保全は，そうした課題に対する有力な解のひとつとなる。

ウィーン市の GB 政策では, STEP05において GB をめぐる 計画規制の強化及び拡充の方向が示されており, それは都市周辺 農林地や公園・庭園など都市内緑地のもつ様々な環境保全機能を 発現させることを意図したものであった。すなわち, 都市に近接 した広域緑地である GB を, 都市内緑地之関連付けて捉え, その 設置意義を，環境保全機能の発現によって得られる市民の生活の 質の向上や, 都市の持続可能性の保証に求めたのである。このよ うに，ウィーン市の GB 政策は，GB の位置づけ及び設置目的を， 環状緑地帯による都市空間の物理的制御から, 体系的な緑地群に よる環境保全機能の発現へと転換させた点において, 注目に值す るものであろう。

今日，世界の都市とくに先進国の諸都市の多くは，経済競争の 激化や産業構造の変化, 農林業の衰退のなかで, 人口が減少に転 じているにもかかわらず, 都市内に残存する緑地や都市周囲の広 域緑地を開発予備地と見なし, 都市圈を拡大する方向にある。そ うした政策は，短期的には都市に経済活性をもたらすかもしれな いが，長期的には持続性という観点において，むしろ多大な負 債を都市にもたらすものとなろう。ウィーン市の GB 政策は，今 後, 持続性という新たな課題に直面することになる世界各国の都 市が, 広域緑地, 及び都市内緑地をいかに保全するかという点に 対して，多くの示唆をもたらすものと考えられる。

なお，こうしたウィーン市の GB 政策の成功の理由を子細に解 明するには, GB 政策の具体的な運用状況等を検討する必要があ ろう。しかし本稿では，この点までは明らかにするまでには至ら
なかった。今後の研究における課題としたい。

謝辞

ウィーン市での現地調查にあたっては, ウィーン市当局 Gisa Ruland 女史にお世話になりました。ここに記して謝辞とさせて いただきます。

\section{引用文献・補注}

1) Amati, M. (2005) : A study on the planning processes and future directions of the London Green Belt An investigation of local level planning, doctoral thesis of University of Tsukuba (Policy and Planning Sciences), 155pp.

2 ) 周藤利一・越澤明（2004）：韓国のグリーンベルト制度の歴史及び効果に 関する研究 : 都市計画学会論文集 39-2, 95-104

3 ）服部圭郎（2005）：グリーンベルトを都市計画に実践した 4 つの都市：Bio City (30), 42-47

4) Stadt Wien (2005) : STEP05 Stadtentwicklungsplan Wien 2005, 244pp

5 ) 三島伸雄・山田学（1994）：隣接建築物との関係から見たウィーン市の連 続壁面タウンスケープの評価と分析一建築史上の著名建築家による建築作 品を中心としてー：都市計画学会論文集 $29,559-564$

6 ）三島伸雄 （1996）：ウィーン市の歴史的景観保全制度の展開と市民意識に 見るその役割：都市計画学会論文集 $31 ， 217-564$

7 ）三島伸雄（2000）：ウィーンの F/B プラン策定におけるグリーンベルト保 全の争点に関する考察一保護指定地域に対するヌスベルク通り 18 番地訟問 題を通して一：都市計画学会論文集 35，979-984

8 ）三島伸雄（2000）：地区詳細計画と風景計画による都市風景の創造：西村 幸夫・街並み研究会（編著）「都市の風景計画」：学芸出版社, $198 \mathrm{pp}$, 92-111 に所収

9 ）三島伸雄（2003）：健康的住まいとしてのウィーンのクラインガルテンに 関わる法改正と空間実態 : 都市計画学会論文集 38-3, 31-36

10) 加藤哲男 (2002) : ウィーンの都市計画 : 名古屋産業大学紀要 第 2 号, 54-61

11) PlanSinn (2005a) : 100 jahre Wiener Wald- und Wiesengürtel, 19052005, Der Stand der Dinge, 196pp

12） 1997 年設立。多分野の専門家から構成されており，分野間の横断が求めら れる事業（都市・緑地・環境計画などの公共事業計画策定等）を担当する。

13) PlanSinn (2005) : 100 Jahre Wald- und Wiesengürtel -ein Werdegang, 100 jahre Wiener Wald- und Wiesengürtel, 1905-2005, Der Stand der Dinge, 73-83.

14）ウィーン州建設法において，以下の制限が課せられる。土地利用（第 6 条） : 農林地としての利用は認可。建設物（第 6 条）：農林業, レクリエーショ ン，緑地管理のための施設は建設可能。住宅は建設禁止。特例許可（第 5 条）：ワイナリーや民宿等に関して規定あり ${ }^{13)}$

15）当時の計画によると $5,860 \mathrm{ha}$ の指定が明記されているが，別の報告書によ ると 4,400ha とされており，正確な值は定かではない ${ }^{13)} 。$

16) Meinhard, B. and Gisa, R. : The Vienna Green Belt- From local protection to a regional concept. (printing)

17) Elisabeth, J. (2005) : Der Garten Wiens- Umweltgeschichte und Landschaftswahrnehmung, 100 jahre Wiener Wald- und Wiesengürtel, 1905-2005, Der Stand der Dinge, 18-27.

18) Stadt Wien (2006) : Vienna Fact \& Figures, Wien international .at $<$ http://www.wieninternational.at/en/node/470>, reference 2007.9.5, update 2006.

19) PlanSinn (2005c) : Das Entstehen der Stadt von der ersten Gründerzeit bis heute, 100 jahre Wiener Wald- und Wiesengürtel, 1905-2005, Der Stand der Dinge, 62-72.

20）農地としての利用が促進される地域。農業のための施設は建設可能など, Sww に比へ積極的な農地利用が可能。2003 年までに 336 ha が指定を受け ている ${ }^{13)}$ 。

21) City of Vienna Municipal Department 18 (2000) : The green belt of Vienna (summary), pp10

22) PlanSinn (2005d) : Die Großen Fünf im Überblick, 100 jahre Wiener Wald- und Wiesengürtel, 1905-2005, Der Stand der Dinge, 8-17.

23) Central European Region (2007) : Goals of project CENTROPE, $<\mathrm{http}: / /$ centrope.com/centropenew $>$, reference 2007.9.12, update 2007.

24）具体的には，都心高密地区（容皘率 200～300\%，少なくと屯 3-4 階建て）, 開発集中軸（容積率 100 200\%，中密中層)，郊外低密地区（容積率 100\% 以下，さらに小規模住宅においては $50 \%$ 以下，低密低層)。

25) PlanSinn (2005e): Das Marchfeld- die bäuerliche Seite der Stadt, 100 jahre Wiener Wald- und Wiesengürtel, 1905-2005, Der Stand der Dinge, 148-155.

26) A, Mrkvicka. (2005) : Der Biosphärenpark - neue Chancen für den Wienerwald, 100 jahre Wiener Wald- und Wiesengürtel, 1905-2005, Der Stand der Dinge, 124-131.

27） 2007 年 7 月 18 日に, MA18 と MA48 の担当局員に対して行った。

28）参考までに，ある単身世帯（女性）で 15,000 円/月程度という事であった。

29）マルコ・アマティ・横張真（2005）：ロンドン・グリーンベルト 政策の階 層化とボトムアップ化による計画の未来 : Bio City (30), 18-22 